\title{
Perkembangan dan Karakterisasi Desa-desa Pegunungan Jawa Tengah
}

\author{
Development and Characterization of Mountain Villages in Central Java
}

\author{
Andi Yoga Saputra ${ }^{1,2 *}$, Ernan Rustiadi ${ }^{2,3} \&$ Wiwiek Rindayati ${ }^{4}$ \\ ${ }^{1}$ Magister Ilmu Perencanaan Pembangunan Wilayah dan Perdesaan, Sekolah Pascasarjana, IPB University, \\ Kampus IPB Dramaga, Bogor 16680, Indonesia; ${ }^{2}$ Pusat Pengkajian Perencanaan dan Pengembangan \\ Wilayah, IPB University, Kampus IPB Baranang Siang, Bogor 16127, Indonesia; ${ }^{3}$ Divisi Perencanaan \\ Pengembangan Wilayah, Departemen Ilmu Tanah dan Sumberdaya Lahan, Fakultas Pertanian, IPB \\ University, Kampus IPB Dramaga, Bogor 16680, Indonesia; ${ }^{4}$ Departemen Ilmu Ekonomi, Fakultas Ekonomi \\ dan Manajemen, IPB University, Kampus IPB Dramaga, Bogor 16680, Indonesia; \\ *Penulis korespondensi.e-mail: andi_yogas@apps.ipb.ac.id \\ (Diterima: 19 Juli 2021; Disetujui: 29 Oktober 2021)
}

\begin{abstract}
The characteristics of mountain villages are very different from valley villages and plain villages, but socio-economically and environmentally related to each other. This study aims to analyze the level of development of physical facilities in mountain villages, analyze the village development index based on the dimensions of village development, and analyze the components of socio-economic, environmental, and developmental characteristics of mountainous villages in Central Java. Analysis of the level of development of mountainous village physical facilities used skalogram based on PODES 2018 data, village development index based on the dimensions of village development used the Village Index (ID) calculation formula, and analysis of the characteristics of the socio-economic, environmental, and developmental components of mountain villages used Principal Component Analysis (PCA). Results of the analysis of the level of development of the physical facilities of the mountainous villages show that 413 villages (67.81\%) of the mountains are in the third hierarchical class (less developed). The category of village development based on the dimensions of development shows that mountain villages are included in the category of developing villages with an average value of ID 54.17. The components that best characterize the characteristics of mountainous villages are the potential for the danger of $21.9 \%$, the availability of secondary school education facilities, health facilities, and the village development level of $16 \%$, the component of trade facilities 5.8. \%, the component of the availability of the micro-industry is $13.25 \%$, and the component of the availability of health facilities are $8.8 \%$.
\end{abstract}

Keywords: mountain village, potential disaster, skalogram, underdeveloped village.

\begin{abstract}
ABSTRAK
Karakteristik desa pegunungan sangat berbeda dengan desa lembah dan desa dataran, namun secara sosial-ekonomi dan lingkungan saling berkaitan. Penelitian ini bertujuan untuk menganalisis tingkat perkembangan fasilitas fisik desa pegunungan, menganalisis indeks perkembangan desa berbasis dimensi pembangunan desa, dan menganalisis komponen-komponen karakteristik sosialekonomi, lingkungan, dan perkembangan desa pegunungan di Jawa Tengah. Analisis tingkat perkembangan fasilitas fisik desa pegunungan menggunakan analisis Skalogram berdasarkan data Potensi Desa (PODES) tahun 2018, indeks perkembangan desa berbasis dimensi pembangunan desa
\end{abstract}


menggunakan rumus perhitungan Indeks Desa (ID), dan analisis komponen-komponen karakteristik sosial-ekonomi, lingkungan, dan perkembangan desa pegunungan menggunakan analisis Principal Component Analysis (PCA). Hasil analisis tingkat perkembangan fasilitas fisik desa pegunungan menunjukkan bahwa 413 desa $(67.81 \%)$ pegunungan masuk dalam kelas hierarki III (kurang berkembang). Kategori perkembangan desa berbasis dimensi pembangunan menunjukkan bahwa seluruh desa pegunungan termasuk ke dalam kategori desa berkembang dengan nilai rata-rata ID 54.17. Hal yang paling mencirikan karakteristik desa pegunungan adalah tingginya potensi risiko bencana sebesar $21.9 \%$, tingginya ketersediaan fasilitas pendidikan sekolah menengah, fasilitas kesehatan, dan tingkat perkembangan desa sebesar 16\%, komponen fasilitas perdagangan sebesar $5.8 \%$, komponen ketersediaan industri mikro sebesar $13.25 \%$, dan komponen ketersediaan fasilitas kesehatan sebesar $8.8 \%$.

Kata kunci: desa pegunungan, desa tertinggal, potensi bencana, skalogram

\section{PENDAHULUAN}

Desa berdasarkan topografi wilayahnya dibagi menjadi tiga kategori yaitu desa lereng/puncak, desa lembah, dan desa dataran (BPS, 2018). Karakteristik dari desa lereng/puncak pegunungan sangat berbeda dengan desa lembah dan desa dataran, akan tetapi secara sosial-ekonomi dan lingkungan saling terkait satu sama lain. Apabila dilihat dari fasilitas dasar dan kesempatan kerja, desa pegunungan memiliki keterbatasan apabila dibandingkan dengan desa lembah maupun desa dataran. Letak geografis desa pegunungan menjadi salah satu penyebab kondisi sosial dan ekonomi penduduk desa pegunungan lebih rendah dibandingkan dengan penduduk desa di dataran rendah (Zhou et al., 2018). Keterbatasan yang dimiliki desa-desa pegunungan menjadikan wilayah ini perlu upaya tambahan agar kesenjangan ekonomi antara perkotaan dan pedesaan dapat diatasi (Nishino, 2010).

Desa Pegunungan merupakan desa yang memiliki tingkat kesuburan tanah yang tinggi, sehingga cocok untuk dijadikan sebagai lokasi pengembangan pertanian. Pertanian menjadi salah satu sumber utama mata pencaharian masyarakat yang tinggal di desa pegunungan (Zollet \& Que, 2012). Provinsi Jawa Tengah sendiri memiliki komoditas pertanian khas desa pegunungan yang menjadi penyumbang produksi terbesar pada tahun 2018 yaitu kubis dan kentang (BPS, 2019).
Secara geografis desa-desa yang berada di daerah perbukitan/pegunungan, pedalaman, dan kepulauan sulit untuk dijangkau oleh jaringan transportasi dan jaringan telekomunikasi, sehingga sebagian besar daerah-daerah tersebut termasuk ke dalam daerah tertinggal (Palupi $e t$ al., 2016). Keterbatasan tersebut mengakibatkan pada masyarakat yang berada di daerah dataran tinggi dan masyarakat di sekitar hutan terjebak pada kantong-kantong kemiskinan (Tisniwati, 2012).

Letak desa pegunungan yang berada di ketinggian menjadikan wilayah ini memiliki fungsi pelindung bagi daerah di bawahnya. Salah satu fungsi penting yang dimiliki oleh desa pegunungan adalah sebagai daerah tangkapan air hujan (catchment area). Selain dapat memenuhi kebutuhan air tanah di wilayah sekitar, daerah tangkapan air hujan juga dapat mencegah terjadinya banjir pada daerah di bawahnya (Amri \& Syukron, 2014).

Desa-desa di Jawa Tengah terutama di desa pegunungan merupakan desa yang rentan terhadap bencana alam. Risiko bencana alam yang terjadi yakni tanah longsor dan angin puting beliung. Tercatat bahwa telah terjadi bencana alam di desa pegunungan pada tahun 2018 yakni tanah longsor sebanyak 381 kejadian dan 54 kejadian angin puting beliung (BPS, 2018). Terjadinya tanah longsor dapat dipicu oleh curah hujan yang tinggi atau disebabkan oleh perilaku manusia. Bahaya tanah longsor semakin tinggi apabila semakin besar harkat kemiringan lereng, pelapukan batuan, struktur 
perlapisan batuan, dan tekstur tanah yang berpasir (Priyono et al., 2006).

Berkaitan dengan pembangunan wilayah desa, terdapat isu-isu strategis pembangunan desa dan kawasan perdesaan. Pertama, mengenai kesejahteraan dan kualitas hidup masyarakat desa (kemiskinan). Kedua, terkait pembangunan sarana dan prasarana di desa dan kawasan perdesaan. Ketiga, keberdayaan dan kemandirian masyarakat perdesaan dimana akar dari ketidakberdayaan masyarakat desa disebabkan oleh faktor ekonomi maupun non ekonomi. Keempat yaitu tata kelola pemerintahan desa dan kelembagaan. Kelima, pemanfaatan sumber daya alam dan lingkungan secara berkelanjutan (Budiarto et al., 2017).

Perkembangan wilayah di desa-desa pegunungan dapat dilihat dari ketersediaan fasilitas fisik dan kemudahan aksesibilitas. Penelitian ini fokus mengkaji desa-desa pegunungan di Jawa Tengah dengan melihat perkembangan dan karakterisasinya. Menurut Zhou et al. (2018), perkembangan desa pegunungan selalu disesuaikan dengan topografi dan kondisi hidrologi. Sehingga perlu dianalisis bagaimana karakteristik sosial-ekonomi, lingkungan, dan perkembangan desa-desa pegunungan di Provinsi Jawa Tengah. Untuk menjawab pertanyaan tersebut, tujuan pada penelitian ini adalah (1) menganalisis tingkat perkembangan fasilitas fisik desa pegunungan; (2) menganalisis indeks perkembangan desa berbasis dimensi pembangunan desa; serta (3) menganalisis karakteristik sosial-ekonomi, lingkungan, dan perkembangan desa pegunungan di Jawa Tengah.

\section{METODOLOGI}

\section{Jenis dan Sumber Data}

Penelitian ini menggunakan data sekunder, yaitu data Potensi Desa Jawa Tengah tahun 2018 yang bersumber dari Badan Pusat Statistik. Penelitian ini meliputi 609 desa pegunungan di Provinsi Jawa Tengah, dimana desa-desa tersebut berada di ketinggian $>750$ Mdpl.

\section{Analisis Tingkat Perkembangan Fasilitas Fisik Desa Pegunungan}

Tingkat perkembangan wilayah dianalisis dengan menggunakan analisis hierarki perkembangan wilayah berdasarkan pada metode skalogram, dari analisis ini diperoleh hierarki untuk masing-masing wilayah (Rustiadi et al., 2011). Metode skalogram berfungsi untuk melihat gambaran tingkat perkembangan pada suatu wilayah secara administratif berdasarkan pada data jarak aksesibilitas, jumlah dan jenis fasilitas yang diperoleh dari data Potensi Desa (Murtadho et al., 2018).

Data yang digunakan dalam analisis ini bersumber dari data PODES (Potensi Desa) tahun 2018 yang terdiri dari variabel jarak terhadap fasilitas tertentu (aksesibilitas) sebanyak 4 variabel dan 69 variabel jenis fasilitas. Variabel jenis fasilitas terdiri atas 32 fasilitas pendidikan, 16 fasilitas kesehatan, dan 21 fasilitas ekonomi.

Tahapan analisis skalogram menurut Panuju \& Rustiadi (2013) terdiri dari melakukan pemilihan terhadap data yang bersifat kuantitatif. Selanjutnya diseleksi berdasarkan parameter yang ditentukan sehingga data yang relevan saja yang digunakan. Tahapan selanjutnya melakukan penjumlahan terhadap desa-desa yang terdapat dalam satu kecamatan yang sama sehingga didapat adalah Hierarki relatif kecamatan, memisahkan antara jarak dan jumlah fasilitas, serta melakukan rasionalisasi data terhadap data jarak dan fasilitas. Data jarak diinvers dengan rumus:

$$
y=\frac{1}{X_{i j}}
$$

Y : variabel baru

$\mathrm{Xij} \quad$ : data jarak j di wilayah $\mathrm{i}$

Min $(\mathrm{I})_{\mathrm{j}}$ : Nilai minimum untuk jenis sarana ke-j.

Setelah didapatkan invers terhadap jarak kemudian dihitung kapasitas pelayanan dari fasilitas tersebut dengan rumus jumlah fasilitas $\mathrm{j}$ di wilayah i dibagi dengan jumlah penduduk di wilayah i. Selanjutnya melakukan pembobotan terhadap data kapasitas dengan cara data 
kapasitas j dibagi dengan bobot fasilitas $\mathrm{j}$, dengan rumus:

$\mathrm{I}: 1,2, \ldots \ldots, \mathrm{n}$;

$$
\text { Iij }=\frac{X i j n j}{X . j a j}
$$

$\mathrm{J}:$ jumlah wilayah $1,2, \ldots \ldots, \mathrm{n}$

Tahapan akhir dari analisis ini adalah menyusun nilai indeks perkembangan wilayah (IPW) di masing-masing desa dengan menggunakan rumus:

$$
\mathbf{K}_{\mathrm{ij}} \frac{\mathbf{I}_{\mathrm{ij}}-\min (\mathbf{I})_{\mathbf{j}}}{\mathbf{S}_{\mathbf{j}}}
$$

$\mathrm{K}_{\mathrm{ij}} \quad$ : Nilai baku untuk desa ke-i dan jenis sarana ke-j

$\mathrm{I}_{\mathrm{ij}} \quad$ : Nilai bobot untuk desa ke-i dan jenis sarana ke-j

Min $(\mathrm{I})_{\mathrm{j}}$ : Nilai minimum untuk jenis sarana ke-j $\mathrm{S}_{\mathrm{i}} \quad$ : Nilai standar deviasi

Setelah dilakukan proses pembakuan, langkah berikutnya yaitu dilakukan teknik sortasi (pengurutan) data dimana wilayah yang mempunyai nilai yang paling besar diletakkan di barisan atas dan fasilitas yang paling banyak berada di kolom kiri. Pada penelitian ini analisis skalogram dilakukan pada level desa. Hasil analisis skalogram berupa IPW tingkat desa kemudian dikelompokkan ke dalam tiga kelas Hierarki, yaitu Hierarki 1 (berkembang), Hierarki 2 (cukup berkembang), dan Hierarki 3 (kurang berkembang). Termasuk kelas hierarki 1 apabila nilai IPW lebih besar daripada nilai rataan ditambah standar deviasi. Sedangkan hierarki 2 dan 3 apabila nilai IPW lebih besar atau sama dengan nilai rataan.

\section{Analisis Indeks Perkembangan Desa \\ Berbasis Dimensi Pembangunan Desa}

Indeks Desa (ID) adalah hasil harmonisasi dua indikator pembangunan desa yaitu Indeks Desa Membangun (IDM) dan Indeks Pembangunan Desa (IPD) (BPS, 2020). Analisis faktor dengan menghitung nilai indeks komposit satu persatu dimensi pembangunan desa menggunakan rumus perhitungan ID digunakan untuk mendapatkan dimensi pembangunan desa di desa-desa pegunungan Jawa Tengah. Kemudian dilakukan proses penghitungan nilai indeks gabungan dari semua dimensi pembangunan tersebut. Perhitungan ini dilakukan pada data Podes 2018. Menurut Badan Pusat Statistik (2020), dalam ID terdapat 6 (enam) karakteristik/dimensi pembangunan desa yang dibangun berdasarkan indikator/variabel dari hasil sensus Podes. Keenam dimensi pembangunan dan indikator pembangunan tersebut adalah sebagai berikut:

1. Dimensi Sarana Prasarana, terdiri dari 4 (empat) indikator yaitu:
a. Sumber Air untuk Mandi/Cuci
b. Bahan Bakar Memasak
c. Waktu Tempuh per Kilometer ke Kantor Camat
d. Persentase Keluarga di Rumah Kumuh

2. Dimensi Pelayanan Dasar, terdiri dari 6 (enam) indikator yaitu:
a. Akses TK/PAUD
b. Akses SD/Sederajat
c. Akses SMP/Sederajat
d. Akses SMA/Sederajat
e. Akses Poskesdes/Polindes
f. Posyandu yang Aktif Bulanan

3. Dimensi Ekonomi, terdiri dari 8 (delapan) indikator yaitu:
a. Keberadaan Pasar Desa
b. Akses ke Bank
c. Keberadaan UMKM
d. Keberadaan Kantor POS/Perusahaan Ekspedisi
e. Keberadaan KUD/BUMDes
f. Akses Listrik
g. Keberadaan Angkutan Umum
h. Layanan Telekomunikasi

4. Dimensi Sosial, terdiri dari 6 (enam) indikator yaitu:
a. Kegiatan Warga Menjaga
Keamanan Lingkungan
b. Keberadaan Fasilitas Olahraga dan Ruang Publik Terbuka
c. Taman Bacaan Masyarakat
d. Musyawarah Desa
e. Konflik Sosial/Perkelahian Massal di Desa


f. Kegiatan Gotong Royong

5. Dimensi Lingkungan, terdiri dari 4 (empat) indikator yaitu:
a. Sistem Pembuangan Sampah
b. Pengelolaan/Daur Ulang Sampah/Limbah
c. Fasilitas Buang Air Besar
d. Usaha Mitigasi Bencana

6. Dimensi Pemerintahan Desa, terdiri dari 4 (empat) indikator yaitu:
a. Kelengkapan Pemerintah Desa
b. Aset Desa
c. Fasilitas Pendukung Kantor Desa
d. Keberadaan Peta Desa yang ditetapkan oleh Peraturan Bupati atau Gubernur

Untuk mendapatkan nilai ID satu desa, maka dilakukan 3 (tiga) tahapan perhitungan dengan setiap tahapan sebagai berikut:

1. Penghitungan skor indikator. Pada tahap setiap indikator diberikan skor 1 hingga 5, dimana skor ini ditentukan berdasarkan masing-masing nilai yang didapatkan dari indikator Podes dalam tabel masingmasing dimensi.

2. Perhitungan indeks dimensi. Penghitungan Dimensi Indeks Desa dihitung dari setiap indikator penyusunnya. Dimensi Indeks Desa merupakan rata-rata aritmatikan tak terimbang dari setiap indikator penyusunan dimensi yang bersangkutan. Formulasi penghitungan indeks dimensi adalah sebagai berikut:

- Indeks Dimensi 1

$(\mathrm{D} 1)=\frac{I_{11}+I_{12}+I_{13}+I_{14}}{4}$

- Indeks Dimensi 2

$(\mathrm{D} 2)=\frac{I_{21}+I_{22}+I_{23}+I_{24}+I_{25}+I_{26}}{6}$

- Indeks Dimensi 3

(D3) $=\frac{I_{31}+I_{32}+I_{33}+I_{34}+I_{35}+I_{36}+I_{37}+I_{38}}{8}$

- Indeks Dimensi 4

(D4) $=\frac{I_{41}+I_{42}+I_{43}+I_{44}+I_{45}+I_{46}}{6}$

- Indeks Dimensi 5

$(\mathrm{D} 5)=\frac{I_{51}+I_{52}+I_{53}+I_{54}}{4}$

- Indeks Dimensi 6
(D6) $=\frac{I_{61}+I_{62}+I_{63}+I_{64}}{4}$

3. Perhitungan indeks desa. Indeks Desa (ID) didapatkan dari hasil proses rata-rata geometrik dari setiap indikator penyusun Indeks Desa. Penghitungan ini diformulasikan sebagai berikut:

$I D=(\sqrt[6]{D 1 \times D 2 \times D 3 \times D 4 \times D 5 \times D 6}) \times 20$

Dari hasil formulasi di atas diperoleh Indeks Desa dengan skala 0 hingga 100. Selanjutnya Indeks Desa dikelompokkan menjadi 5 (lima) kategori sesuai perolehan nilai ID dengan kategori sebagai berikut (BPS, 2020):

1. Desa Sangat Tertinggal (0 sampai 34.99)

2. Desa Tertinggal (35 sampai 49.99)

3. Desa Berkembang (50 sampai 64.99)

4. Desa Maju (65 sampai 79.99)

5. Desa Mandiri (90 sampai 100)

\section{Analisis Komponen Karakteristik Sosial-} Ekonomi, Lingkungan, dan Perkembangan Desa

Pada analisis karakteristik sosial, ekonomi, dan lingkungan desa-desa pegunungan Jawa Tengah digunakan analisis Principal Component Analysis (PCA). Analisis Komponen Utama (PCA) adalah teknik multivariat yang menganalisis tabel data dimana pengamatan dijelaskan oleh beberapa variabel dependen kuantitatif yang saling berkorelasi (Mishra et al., 2017). Secara prinsip, metode Principal Component Analysis (PCA) bertujuan untuk menyederhanakan variabel yang diamati dengan cara mereduksi dimensinya.

Pada penelitian ini penentuan desa-desa pegunungan mengacu kepada data Potensi Desa 2018 (BPS), dengan tahapan melakukan self validation dikerjakan sendiri oleh peneliti dengan mengumpulkan seluruh indikator yang kemungkinan dapat digunakan untuk menilai desa-desa kawasan pegunungan. Selanjutnya dilakukan validasi dengan menggunakan metode Principal Component Analysis (PCA). Metode PCA secara matematis dapat diformulasikan sebagai berikut: 
$\begin{array}{ll}\text { Keterangan: } & \\ \text { PC1,PC2,PCn } & \text { : Principal Component ke-n dari } \\ & \text { masing-masing variabel } \\ \alpha & : \text { Koefisien regresi dari masing- } \\ & \text { masing variabel }(\mathrm{X} 1, \mathrm{X} 2, \mathrm{Xp}) \\ \mathrm{X} 1, \mathrm{X} 2, \mathrm{Xp} & : \text { Variabel/indikator } \\ \mathrm{p} & \text { : Jumlah variabel/indikator }\end{array}$

$$
\begin{aligned}
& \mathrm{PC} 1=\alpha 11 \mathrm{X} 1+\alpha 12 \mathrm{X} 2+\ldots .+\alpha 1 \mathrm{X} \mathrm{xp} \\
& \mathrm{PC} 2=\alpha 21 \mathrm{X} 1+\alpha 22 \mathrm{X} 2+\ldots .+\alpha 2 \mathrm{Xp} \\
& \mathrm{PCn}=\alpha \mathrm{n} 1 \mathrm{X} 1+\alpha \mathrm{n} 2 \mathrm{X} 2+\ldots .+\alpha \operatorname{nn} \mathrm{Xp}
\end{aligned}
$$$$
\text { masing-masing variabel }
$$

Analisis Komponen Utama (PCA) dilakukan untuk mengetahui faktor yang paling berpengaruh terhadap sistem sosial, ekologi dan ekonomi di desa-desa pegunungan Jawa Tengah berdasarkan data-data yang tersedia. Analisis komponen utama merupakan teknik analisis multivariabel (menggunakan banyak variabel) yang dilakukan untuk tujuan ortogonalisasi dan penyederhanaan variabel (Pratiwi \& Harjoko, 2013). Metode PCA tersebut dilakukan dengan menggunakan perangkat lunak SPSS untuk mendapatkan tingkat kepentingan dari variabel sosial, ekonomi, dan lingkungan serta perkembangan desa. Variabel yang digunakan dalam analisis PCA ini merupakan variabel yang dipilih oleh peneliti yang mencakup dimensi sosial, ekonomi, lingkungan dan nilai indeks perkembangan desa yang dihasilkan dari analisis skalogram. Adapun variabel yang digunakan dapat dilihat pada Tabel 1.

Tabel 1. Variabel yang digunakan dalam analisis

\begin{tabular}{|c|c|c|}
\hline No & Variabel & Kode \\
\hline 8 & $\begin{array}{l}\text { Jumlah sarana kesehatan } \\
\text { Puskesmas pembantu di } \\
\text { desa/kelurahan }\end{array}$ & $\mathrm{X} 8$ \\
\hline 9 & Jumlah Tempat praktek bidan & X9 \\
\hline 10 & Jumlah Toko khusus obat/jamu & $\mathrm{X} 10$ \\
\hline 11 & $\begin{array}{l}\text { Jumlah posyandu dengan } \\
\text { kegiatan/pelayanan setiap sebulan } \\
\text { sekali }\end{array}$ & $\mathrm{X} 11$ \\
\hline 12 & $\begin{array}{l}\text { Industri mikro dan kecil barang } \\
\text { dari kulit (tas, sepatu, sandal, dll.) }\end{array}$ & $\mathrm{X} 12$ \\
\hline 13 & $\begin{array}{l}\text { Industri mikro dan kecil dari kayu } \\
\text { (meja, kursi, lemari, dll.) }\end{array}$ & $\mathrm{X} 13$ \\
\hline 14 & $\begin{array}{l}\text { Industri mikro dan kecil barang } \\
\text { dari kain/tenun (kerajinan tenun, } \\
\text { konveksi, dll.) }\end{array}$ & $\mathrm{X} 14$ \\
\hline 15 & $\begin{array}{l}\text { Industri mikro dan kecil } \\
\text { gerabah/keramik/ batu (genteng, } \\
\text { batu bata, porselin, tegel, keramik, } \\
\text { dll.) }\end{array}$ & $\mathrm{X} 15$ \\
\hline 16 & $\begin{array}{l}\text { Industri mikro dan kecil makanan } \\
\text { dan minuman (pengolahan dan } \\
\text { pengawetan daging, ikan, buah-- } \\
\text { buahan, sayuran, minyak dan } \\
\text { lemak, susu dan makanan dari } \\
\text { susu, makanan dan minuman lain, } \\
\text { dll.) }\end{array}$ & $\mathrm{X} 16$ \\
\hline 17 & $\begin{array}{l}\text { Toko/warung kelontong (tempat } \\
\text { usaha di bangunan tetap untuk } \\
\text { menjual berbagai jenis barang } \\
\text { keperluan sehari-hari secara } \\
\text { eceran tanpa ada sistem pelayanan } \\
\text { mandiri) }\end{array}$ & $\mathrm{X} 17$ \\
\hline 18 & $\begin{array}{l}\text { Toko/warung kelontong yang } \\
\text { menjual bahan pangan (sembako) }\end{array}$ & $\mathrm{X} 18$ \\
\hline 19 & $\begin{array}{l}\text { Banyak kejadian Tanah Longsor } \\
2017\end{array}$ & $\mathrm{X} 19$ \\
\hline 20 & $\begin{array}{l}\text { Banyak kejadian/bencana Banjir } \\
2017\end{array}$ & $\mathrm{X} 20$ \\
\hline 21 & $\begin{array}{l}\text { Banyak kejadian/bencana Banjir } \\
\text { bandang } 2017\end{array}$ & $\mathrm{X} 21$ \\
\hline 22 & $\begin{array}{l}\text { Banyak kejadian/bencana Gempa } \\
\text { Bumi } 2017\end{array}$ & $\mathrm{X} 22$ \\
\hline 23 & $\begin{array}{l}\text { Banyak kejadian/bencana Angin } \\
\text { puyung/puting beliung/topan } \\
2017\end{array}$ & $\mathrm{X} 23$ \\
\hline 24 & $\begin{array}{l}\text { Banyak kejadian/bencana } \\
\text { Kebakaran hutan dan lahan } 2017\end{array}$ & $\mathrm{X} 24$ \\
\hline 25 & $\begin{array}{l}\text { Banyak kejadian/bencana } \\
\text { Kekeringan (lahan) } 2017\end{array}$ & $\mathrm{X} 25$ \\
\hline 26 & Nilai IPD & $\mathrm{X} 26$ \\
\hline
\end{tabular}
Principal Component Analysis

\begin{tabular}{clc}
\hline No & \multicolumn{1}{c}{ Variabel } & Kode \\
\hline 1 & $\begin{array}{l}\text { Jumlah lembaga pendidikan } \\
\text { TK/RA/BA }\end{array}$ & X1 \\
\hline 2 & $\begin{array}{l}\text { Jumlah lembaga pendidikan } \\
\text { SD/MI }\end{array}$ & X2 \\
\hline 3 & $\begin{array}{l}\text { Jumlah lembaga pendidikan } \\
\text { SMP/MTs }\end{array}$ & X3 \\
\hline 4 & $\begin{array}{l}\text { Jumlah lembaga pendidikan } \\
\text { SMU/MA }\end{array}$ & X4 \\
\hline 5 & Jumlah lembaga pendidikan SMK & X5 \\
\hline 6 & $\begin{array}{l}\text { Jumlah sarana kesehatan } \\
\text { Puskesmas dengan rawat inap di } \\
\text { desa/kelurahan }\end{array}$ & X6 \\
\hline 7 & $\begin{array}{l}\text { Jumlah sarana kesehatan } \\
\text { Puskesmas tanpa rawat inap di } \\
\text { desa/kelurahan }\end{array}$ & X7 \\
\hline
\end{tabular}




\section{HASIL DAN PEMBAHASAN}

Desa pegunungan merupakan desa yang terletak diatas $750 \mathrm{Mdpl}$ (Istiawan, 2019). Berdasarkan pengertian ini desa-desa yang termasuk ke dalam desa pegunungan di Jawa Tengah sebanyak 609 desa yang tersebar di 18 kabupaten, yakni Kabupaten Banjarnegara (90 desa), Kabupaten Banyumas (15 desa), Kabupaten Batang (24 desa), Kabupaten Boyolali (29 desa), Kabupaten Brebes (17 desa), Kabupaten Kendal (12 desa), Kabupaten Klaten (2 desa), Kabupaten Kudus (4 desa), Kabupaten Magelang (66 desa), Kabupaten Pati (4 desa), Kabupaten Pekalongan (22 desa), Kabupaten Pemalang (16 desa), Kabupaten Purbalingga (15 desa), Kabupaten Purworejo (6 desa), Kabupaten Semarang (40 desa), Kabupaten Tegal (15 desa), Kabupaten Temanggung (116 desa), Kabupaten Wonosobo (116 desa), dan Kota Salatiga (1 desa).

Fasilitas pendidikan merupakan penunjang bagi perkembangan pendidikan dan SDM di suatu desa. Tercatat pada tahun 2018 menurut data Potensi Desa di desa-desa pegunungan Jawa Tengah sendiri terdapat 1,022 fasilitas pendidikan tingkat sekolah dasar, 1,422 fasilitas pendidikan tingkat sekolah menengah, dan 316 fasilitas pendidikan tingkat sekolah atas yang tersebar di desa-desa pegunungan Jawa Tengah.

Masyarakat desa pegunungan di Jawa Tengah memiliki sumber mata pencaharian yang cukup bervariasi, mulai bersumber dari sektor pertanian, pertambangan dan penggalian, industri pengolahan, perdagangan, jasa, dan lainnya. Dari data potensi desa tahun 2018 menunjukkan bahwa 94\% sumber penghasilan utama masyarakat desa pegunungan bersumber dari sektor pertanian, sektor perdagangan besar atau eceran dan rumah makan sebesar 3\%, industri pengolahan (pabrik, kerajinan, dll) sebesar $2 \%$, sektor jasa sebesar $0.8 \%$, sektor pertambangan dan penggalian sebesar $0.2 \%$, serta lainnya sebesar $0.3 \%$.

\section{Perkembangan Fasilitas Fisik Desa-desa Pegunungan Jawa Tengah}

Hasil analisis skalogram pada 609 desa pegunungan di Jawa Tengah pada tahun 2018 menunjukkan bahwa rata-rata nilai IPD sebesar 21.09 dengan standar deviasi 18.28. Nilai IPD tertinggi pada tahun 2018 berada di Desa Kaligentong Kecamatan Ampel Kabupaten Boyolali dengan nilai 184.18. Sementara untuk nilai IPD terendah desa pegunungan Jawa Tengah pada tahun 2018 berada di Desa Wonosido Kecamatan Lebakbarang Kabupaten Wonosobo dengan nilai IPD sebesar 3.10.

Jika melihat dari Hierarki wilayahnya, desa-desa pegunungan di Jawa Tengah sebagian besar termasuk ke dalam Hierarki III (kurang berkembang) yaitu sejumlah 413 desa atau $67.81 \%$, Kabupaten Temanggung menjadi daerah dengan desa-desa pegunungannya terbanyak yang termasuk ke dalam hierarki III yakni sebanyak 104 desa. Sebanyak 71 desa atau $11.9 \%$ termasuk ke dalam Hierarki I (berkembang), Kabupaten Magelang menjadi daerah dengan desa-desa pegunungannya masuk ke dalam Hierarki I terbanyak yaitu 21 desa. Sementara terdapat 123 desa pegunungan atau 20.19\% termasuk ke dalam hierarki II (cukup berkembang), Kabupaten Banjarnegara menjadi daerah dengan desa-desa pegunungannya masuk ke dalam hierarki II yaitu sebanyak 33 desa.

Masih banyaknya desa-desa pegunungan di Jawa Tengah yang masuk ke dalam kelas hierarki III, hal tersebut menunjukkan bahwa dengan adanya kebijakan dana desa, tidak mempunyai pengaruh yang signifikan terhadap ketersediaan fasilitas fisik di desa-desa pegunungan di Jawa Tengah. Yulitasari \& Tyas (2020) peningkatan jumlah dana desa yang diberikan kepada desa setiap tahunnya perlu dilakukan evaluasi terhadap dampaknya kepada perkembangan dan pembangunan desa. Hierarki perkembangan wilayah di desa-desa pegunungan Jawa Tengah tahun 2018 dapat dilihat pada Tabel 2 . 
Tabel 2. Hierarki perkembangan wilayah di desa pegunungan Jawa Tengah tahun 2018

\begin{tabular}{lrrr}
\hline Kabupaten & $\begin{array}{c}\text { Hierarki } \\
\text { I }\end{array}$ & $\begin{array}{c}\text { Hierarki } \\
\text { II }\end{array}$ & $\begin{array}{c}\text { Hierarki } \\
\text { III }\end{array}$ \\
\hline Banjarnegara & 18 & 33 & 39 \\
Banyumas & 8 & 5 & 2 \\
Batang & 7 & 9 & 8 \\
Boyolali & 8 & 11 & 10 \\
Brebes & 5 & 2 & 10 \\
Kendal & 1 & 5 & 6 \\
Klaten & 0 & 0 & 2 \\
Kudus & 1 & 3 & 0 \\
Magelang & 18 & 24 & 24 \\
Pati & 2 & 1 & 1 \\
Pekalongan & 0 & 3 & 19 \\
Pemalang & 0 & 0 & 16 \\
Purbalingga & 0 & 1 & 14 \\
Purworejo & 0 & 0 & 6 \\
Semarang & 0 & 3 & 37 \\
Tegal & 0 & 0 & 15 \\
Temanggung & 1 & 11 & 104 \\
Wonosobo & 4 & 12 & 100 \\
\hline Jumlah & $\mathbf{7 3}$ & $\mathbf{1 2 3}$ & $\mathbf{4 1 3}$ \\
\hline & & & \\
\hline
\end{tabular}

\section{Indeks Perkembangan Desa Berbasis Dimensi Pembangunan Desa}

Indeks Desa adalah hasil harmonisasi dua indikator pembangunan desa yaitu IDM dan IPD (BPS, 2020). Analisis indeks perkembangan desa dengan menghitung nilai indeks komposit satu persatu dimensi pembangunan desa menggunakan rumus perhitungan ID yang digunakan untuk mendapatkan dimensi pembangunan desa di desa-desa pegunungan Jawa Tengah. Kemudian dilakukan proses penghitungan nilai indeks gabungan dari semua dimensi pembangunan tersebut. Perhitungan ini dilakukan pada data Podes 2018.

Pada analisis ini dilakukan penghitungan dimensi Indeks Desa dari setiap indikator penyusunnya. Dari hasil perhitungan tersebut kemudian dikategorikan menjadi 5 kelompok sesuai dengan perolehan nilai ID. Kategorikategori tersebut adalah Desa Sangat Tertinggal (0 hingga 34.99) Desa Tertinggal (35 hingga 49.99), Desa Berkembang (50 hingga 64.99),
Desa Maju (65 hingga 79.99), dan Desa Mandiri (80 hingga 100) (BPS, 2020). Dalam dokumen Rencana Pembangunan Jangka Menengah Nasional (RPJMN) 2020 hingga 2024, kelima kategori di atas dijadikan 3 (tiga) kategori dengan cara menggabungkan kategori desa sangat tertinggal dan desa tertinggal yang dikategorikan sebagai desa tertinggal, berikutnya kategori desa mandiri dan desa maju dijadikan satu kategori menjadi desa mandiri.

Berdasarkan hasil dari analisis indeks perkembangan berbasis dimensi pembangunan desa menunjukkan bahwa rata-rata nilai indeks desa pada desa-desa pegunungan di Jawa Tengah adalah sebesar 54.17. Nilai indeks desa menunjukkan bahwa terdapat satu desa yang termasuk ke dalam kategori desa sangat tertinggal dan 182 desa yang termasuk ke dalam kategori desa tertinggal.

Menurut Octavia et al. (2020) status desa sangat tertinggal dan tertinggal menunjukkan bahwa desa mengalami kerentanan yang disebabkan karena adanya masalah bencana alam, goncangan ekonomi, dan konflik social. Sehingga tidak berkemampuan mengelola potensi sumber daya sosial, ekonomi, dan ekologi.

Desa-desa pegunungan di Jawa Tengah berdasarkan nilai indeks desanya sebagian besar termasuk ke dalam kategori desa berkembang yakni sebanyak 376 desa. Desa-desa dengan kategori desa berkembang ini memiliki potensi sumber daya sosial, ekonomi, dan ekologi tetapi belum secara optimal pengelolaannya untuk peningkatan kesejahteraan masyarakat desa (Sriningsih et al., 2020).

Desa yang termasuk ke dalam kategori desa maju pada desa-desa pegunungan berdasarkan nilai indeks desanya terdapat sebanyak 50 desa. Hal ini menunjukkan bahwa desa dengan kategori maju di desa-desa pegunungan Jawa Tengah masih relatif kecil. Sehingga upaya mewujudkan desa maju dan desa mandiri merupakan tantangan dalam pembangunan desa. Namun desa-desa tersebut dapat dijadikan percontohan bagi pembangunan desa di kawasan lain. 
Tabel 3. Nilai Indeks Desa (ID) desa-desa pegunungan di Jawa Tengah tahun 2018

\begin{tabular}{llccccc}
\hline \multirow{2}{*}{ No } & \multirow{2}{*}{ Kabupaten } & Sangat Tertinggal & Tertinggal & Berkembang & Maju & Mandiri \\
\cline { 3 - 6 } & & 0 & 29 & 53 & 8 & 0 \\
$\mathbf{1}$ & Banjarnegara & 0 & 3 & 10 & 2 & 0 \\
$\mathbf{2}$ & Banyumas & 0 & 12 & 9 & 3 & 0 \\
$\mathbf{3}$ & Batang & 0 & 10 & 18 & 1 & 0 \\
$\mathbf{4}$ & Boyolali & 0 & 3 & 13 & 1 & 0 \\
$\mathbf{5}$ & Brebes & 0 & 6 & 5 & 1 & 0 \\
$\mathbf{6}$ & Kendal & 0 & 0 & 2 & 0 & 0 \\
$\mathbf{7}$ & Klaten & 0 & 0 & 4 & 0 & 0 \\
$\mathbf{8}$ & Kudus & 0 & 15 & 44 & 7 & 0 \\
$\mathbf{9}$ & Magelang & 0 & 3 & 1 & 0 & 0 \\
$\mathbf{1 0}$ & Pati & 0 & 4 & 18 & 0 & 0 \\
$\mathbf{1 1}$ & Pekalongan & 0 & 4 & 9 & 3 & 0 \\
$\mathbf{1 2}$ & Pemalang & 0 & 6 & 9 & 0 & 0 \\
$\mathbf{1 3}$ & Purbalingga & 0 & 3 & 2 & 1 & 0 \\
$\mathbf{1 4}$ & Purworejo & 0 & 3 & 14 & 4 & 0 \\
$\mathbf{1 5}$ & Semarang & 0 & 36 & 70 & 9 & 0 \\
$\mathbf{1 6}$ & Tegal & 1 & 31 & 75 & 10 & 0 \\
$\mathbf{1 7}$ & Temanggung & 0 & $\mathbf{1 8 2}$ & $\mathbf{3 7 6}$ & $\mathbf{5 0}$ & $\mathbf{0}$ \\
$\mathbf{1 8}$ & Wonosobo & $\mathbf{1}$ & & & & 0 \\
\hline & Jumlah & & & 22 & 4 & 0 \\
\hline
\end{tabular}

Komponen-komponen Karakteristik SosialEkonomi, Lingkungan, dan Perkembangan Desa

Sebelum melakukan analisis Principal Component Analysis terhadap 26 variabel yang mewakili 5 bidang yang ada, yaitu pendidikan, kesehatan, ekonomi, lingkungan, dan indeks perkembangan desa, maka yang pertama dilakukan adalah menguji kelayakan data dan korelasi antar variabelnya dengan KMO dan Uji Bartlett. Hasil uji KMO dan Bartlett disajikan pada Tabel 4 berikut.

Tabel 4. Hasil uji Kaiser Meyer Olkim dan Bartlett Kaiser-Meyer-Olkin Measure of $\quad 0.884$ Sampling Adequacy.

\begin{tabular}{llr}
\hline $\begin{array}{l}\text { Bartlett's Test of } \\
\text { Sphericity }\end{array}$ & $\begin{array}{l}\text { Approx. } \\
\text { Chi-Square }\end{array}$ & 1020.0000 \\
\cline { 2 - 3 } & df & 325 \\
\cline { 2 - 3 } & Sig. & 0.000
\end{tabular}

Berdasarkan Tabel 4, memperlihatkan bahwa nilai uji KMO adalah 0.884 yaitu lebih besar dari 0.5. Dari hasil tersebut menunjukkan bahwa variabel dan sampel yang digunakan memungkinkan untuk dilakukan analisis faktor. Hasil chi-square 1020.000 dengan nilai signifikansi 0.000 menunjukkan adanya korelasi antar variabel. Sementara untuk nilai MSA seluruh variabel independen adalah $>0.5$, yang artinya variabel-variabel tersebut dapat dilakukan analisis lanjutan.

Untuk menentukan jumlah faktor yang terbentuk dapat didasarkan pada nilai eigenvalue. Nilai eigenvalue $\geq 1$ yang dianggap sebagai suatu faktor (Sitinjak et al., 2017). Dari 26 variabel yang menjadi input PCA, kemudian diperoleh nilai cumulative dari variabel baru sebesar $65.99 \%$ yang menandakan variabel baru telah valid (\%cumulative $>65 \%$ ).

Dari Tabel 1 menunjukkan hasil PCA (factor loading) pada 26 variabel yang mempunyai nilai $>0.5$ terdiri atas 8 (delapan) faktor yang meliputi:

1. Faktor 1 terdiri atas $\mathrm{X} 19, \mathrm{X} 20, \mathrm{X} 21, \mathrm{X} 22$, $\mathrm{X} 23$, dan X25. Pada faktor 1 semua variabel bernilai positif, variabel-variabel tersebut 
menunjukkan karakteristik risiko tinggi bencana yang terjadi di desa-desa pegunungan.

2. Faktor 2 terdiri atas $\mathrm{X} 3, \mathrm{X} 4, \mathrm{X} 5, \mathrm{X} 6, \mathrm{X} 10$, dan X26. Dimana variabel-variabel tersebut menunjukkan karakteristik tingginya ketersediaan fasilitas pendidikan sekolah menengah, fasilitas kesehatan dan tingkat perkembangan desa-desa pegunungan Jawa Tengah.

3. Faktor 3 terdiri atas X17 dan X18 yang menunjukkan karakteristik ketersediaan fasilitas toko kebutuhan pokok, sandang, dan papan di desa-desa pegunungan.

4. Faktor 4 terdiri atas X14, variabel ini menunjukkan karakteristik keberadaan fasilitas industri mikro kecil kain/tenun.
5. Faktor 5 terdiri atas $\mathrm{X} 8$, variabel ini merupakan karakteristik ketersediaan fasilitas kesehatan di desa pegunungan.

6. Faktor 6 terdiri atas X7, variabel ini menunjukkan karakteristik ketersediaan fasilitas kesehatan di Desa Pegunungan.

7. Faktor 7 terdiri atas X12 dan X13 variabelvariabel tersebut menunjukkan karakteristik ketersediaan industri mikro dan kecil dari kulit dan dari kayu.

8. Faktor 8 terdiri atas X16 dan X24. Pada faktor 8 terlihat nilai X24 bernilai negatif sedangkan nilai variabel X16 positif. Variabel pada faktor 8 ini menunjukkan karakteristik ketersediaan industri mikro kecil makanan/minuman dan rendahnya risiko bencana kebakaran.

Tabel 5. Hasil factor loading analysis Principal Component Analysis

\begin{tabular}{lrrrrrrrr}
\hline Variabel & \multicolumn{7}{c}{ Faktor } \\
\cline { 2 - 9 } X1 & $\mathbf{1}$ & $\mathbf{2}$ & $\mathbf{3}$ & $\mathbf{4}$ & $\mathbf{5}$ & $\mathbf{6}$ & $\mathbf{7}$ & $\mathbf{8}$ \\
X2 & -0.038 & 0.424 & 0.468 & 0.275 & 0.290 & 0.211 & 0.021 & -0.204 \\
X3 & -0.063 & 0.355 & 0.370 & 0.281 & 0.422 & 0.291 & -0.061 & -0.034 \\
X4 & -0.024 & $\mathbf{0 . 5 4 7}$ & 0.225 & 0.086 & 0.129 & 0.252 & -0.071 & 0.061 \\
X5 & 0.003 & $\mathbf{0 . 6 9 5}$ & -0.033 & -0.031 & 0.115 & -0.010 & 0.177 & 0.057 \\
X6 & -0.007 & $\mathbf{0 . 5 7 2}$ & 0.068 & -0.017 & -0.108 & 0.084 & 0.019 & 0.174 \\
X7 & -0.009 & $\mathbf{0 . 5 8 4}$ & 0.206 & -0.044 & -0.195 & -0.467 & -0.170 & -0.103 \\
X8 & -0.006 & 0.135 & 0.241 & 0.049 & -0.163 & $\mathbf{0 . 7 2 0}$ & -0.058 & 0.072 \\
X9 & -0.011 & -0.002 & -0.042 & -0.114 & $\mathbf{0 . 7 4 9}$ & -0.111 & 0.041 & -0.065 \\
X10 & -0.045 & 0.452 & 0.041 & 0.475 & 0.102 & 0.134 & 0.033 & -0.019 \\
X11 & 0.000 & $\mathbf{0 . 5 5 0}$ & 0.205 & -0.065 & -0.046 & 0.132 & 0.225 & -0.237 \\
X12 & -0.049 & 0.224 & 0.447 & 0.239 & 0.436 & 0.310 & -0.113 & -0.012 \\
X13 & -0.002 & 0.010 & 0.088 & 0.033 & -0.054 & -0.004 & $\mathbf{0 . 8 0 3}$ & -0.111 \\
X14 & -0.013 & 0.184 & 0.077 & 0.222 & 0.236 & -0.011 & $\mathbf{0 . 5 5 7}$ & 0.350 \\
X15 & 0.000 & 0.001 & 0.013 & $\mathbf{0 . 8 3 2}$ & -0.104 & 0.004 & 0.158 & -0.014 \\
X16 & -0.008 & -0.103 & 0.284 & 0.311 & -0.057 & -0.348 & -0.110 & 0.198 \\
X17 & -0.008 & 0.033 & 0.257 & 0.004 & 0.402 & -0.103 & 0.140 & $\mathbf{0 . 5 7 1}$ \\
X18 & 0.003 & 0.146 & $\mathbf{0 . 7 9 1}$ & 0.147 & 0.004 & -0.029 & 0.193 & 0.058 \\
X19 & 0.017 & 0.113 & $\mathbf{0 . 8 1 0}$ & -0.152 & -0.008 & 0.097 & 0.024 & -0.013 \\
X20 & $\mathbf{0 . 9 9 1}$ & -0.008 & -0.009 & -0.015 & -0.010 & -0.002 & -0.011 & -0.004 \\
X21 & $\mathbf{0 . 9 7 7}$ & -0.001 & -0.005 & -0.009 & -0.014 & -0.004 & 0.010 & -0.009 \\
X22 & $\mathbf{0 . 9 2 3}$ & -0.017 & 0.003 & -0.002 & -0.008 & -0.006 & -0.004 & 0.004 \\
X23 & $\mathbf{0 . 9 9 0}$ & -0.013 & -0.011 & -0.011 & -0.022 & -0.008 & -0.006 & 0.003 \\
X24 & $\mathbf{0 . 9 8 7}$ & -0.007 & 0.003 & -0.007 & -0.018 & -0.009 & 0.018 & -0.006 \\
X25 & 0.003 & -0.068 & 0.111 & 0.026 & 0.242 & -0.106 & 0.079 & $\mathbf{- 0 . 6 6 7}$ \\
X26 & $\mathbf{0 . 9 5 9}$ & -0.021 & -0.005 & -0.011 & 0.006 & 0.001 & -0.016 & 0.000 \\
X1 & 0.001 & $\mathbf{0 . 5 7 8}$ & 0.021 & 0.341 & 0.148 & -0.179 & -0.159 & 0.026 \\
\hline & & & & & & & & \\
\hline
\end{tabular}


Berdasarkan tabel dan uraian di atas, karakteristik desa-desa pegunungan di Jawa Tengan dapat dijelaskan berdasarkan komponen-komponen sebagai berikut:

1. Tingginya potensi risiko bencana $(\mathrm{F} 1)$.

2. Tingginya ketersediaan fasilitas pendidikan sekolah menengah, fasilitas kesehatan, dan tingkat perkembangan desa (F2).

3. Ketersediaan fasilitas perdagangan (F3).

4. Ketersediaan industri mikro (F4,F7,F8).

5. Ketersediaan fasilitas kesehatan (F5,F6).

Desa-desa pegunungan di Jawa Tengah memiliki karakteristik yaitu tingginya potensi risiko bencana. Menurut Murdiyanto \& Gutomo (2015) daerah pegunungan merupakan salah satu daerah yang termasuk rawan terhadap bencana alam terutama banjir bandang dan tanah longsor. Faktor-faktor utama yang berpengaruh terhadap bencana tanah longsor yaitu kelerengan yang sangat curam, alih fungsi lahan dengan tanaman hortikultura yang memerlukan upaya penggemburan tanah dan mengganggu kestabilan lereng, serta curah hujan yang tinggi (Naryanto et al., 2019). Berdasarkan hasil analisis PCA desa dengan karakteristik potensi risiko bencana yang tinggi adalah Desa Citrosono, Kabupaten Magelang. Karakter dari Desa Citrosono adalah berada pada ketinggian 1350 Mdpl serta memiliki kemiringan lereng yang curam.

Karakteristik desa pegunungan di Jawa Tengah yang kedua adalah tingginya ketersediaan fasilitas pendidikan sekolah menengah, fasilitas kesehatan, dan tingkat perkembangan desa. Fasilitas pendidikan dan kesehatan merupakan fasilitas dasar yang harus dipenuhi oleh pemerintah untuk menunjang kualitas hidup yang lebih baik terutama pada desa-desa pegunungan/dataran tinggi. Berdasarkan hasil analisis PCA, salah satu desa yang memiliki karakteristik tingginya fasilitas pendidikan sekolah menengah, fasilitas kesehatan (tempat praktek bidan), dan tingkat perkembangan desa adalah Desa Wonosobo Timur. Desa Wonosobo Timur termasuk desa yang memiliki fasilitas pendidikan dan kesehatan yang lengkap serta berdasarkan analisis skalogram, desa ini termasuk ke dalam desa dengan hierarki I.

Karakteristik desa-desa pegunungan di Jawa Tengah yang ketiga adalah ketersediaan fasilitas perdagangan. Fasilitas perdagangan di desa pegunungan menjadi salah satu fasilitas yang dijadikan sebagai tempat pemenuhan kebutuhan sandang dan pangan. Karakteristik ini digambarkan oleh Desa Tlogopucang Kabupaten Temanggung.

Ketersediaan industri mikro menjadi karakteristik desa-desa pegunungan yang keempat. Pengembangan industri mikro sangat strategis dalam menggerakan perekonomian di desa (Anggraeni et al., 2020). Industri mikro di Jawa Tengah sebagian besar bergerak di sektor pertanian, sektor pertanian ini mencakup berbagai bentuk usaha yang memanfaatkan benda-benda/barang-barang biologis (hidup) (Darwanto et al., 2018). Karakteristik seperti ini ditunjukkan oleh Desa Candimulyo Kabupaten Wonosobo, Desa Cukil Kabupaten Semarang, dan Desa Kaligentong Kabupaten Boyolali.

Karakteristik desa-desa pegunungan Jawa Tengah yang terakhir adalah ketersediaan fasilitas kesehatan. Ketersediaan fasilitas kesehatan bertujuan untuk meningkatkan aksesibilitas penduduk (terutama penduduk miskin) pada pelayanan kesehatan dasar. Ketersediaan fasilitas kesehatan pada desa-desa pegunungan memiliki nilai investasi yang tinggi bagi usaha meningkatkan kesejahteraan masyarakat (Usman et al., 2010). Karakteristik seperti ini digambarkan oleh Desa Batursari Kabupaten Wonosobo dan Desa Jimbaran Kabupaten Semarang.

\section{KESIMPULAN}

Hierarki perkembangan wilayah di desadesa pegunungan di Jawa Tengah menunjukkan bahwa sebagian besar atau $67.81 \%$ desa termasuk ke dalam kelas hierarki III (kurang berkembang). Hal ini menunjukkan bahwa fasilitas di desa-desa pegunungan di Jawa Tengah sebagian besar masih kurang berkembang. Sementara itu hanya 73 atau 11.9\% 
desa saja yang masuk ke dalam hierarki I dan 123 atau $20.19 \%$ desa masuk ke dalam hierarki II.

Apabila dilihat dari sisi kategori pembangunan desa menurut nilai Indeks Desa (ID), rata-rata nilai indeks desa sebesar 54.17. Hal ini menunjukkan bahwa pembangunan yang berada di desa-desa pegunungan di Jawa Tengah masih termasuk kategori desa berkembang.

Hal yang paling mencirikan karakteristik desa pegunungan adalah tingginya potensi risiko bencana sebesar $21.9 \%$, tingginya ketersediaan fasilitas pendidikan sekolah menengah, fasilitas kesehatan, dan tingkat perkembangan desa pegunungan sebesar $16 \%$, komponen fasilitas perdagangan sebesar 5.8\%, komponen ketersediaan industri mikro sebesar $13.25 \%$, dan komponen ketersediaan fasilitas kesehatan sebesar $8.8 \%$.

\section{DAFTAR PUSTAKA}

Amri, K. \& Syukron, A. (2014). Analisis Debit Puncak Das Padang Guci Kabupaten Kaur Provinsi Bengkulu. Jurnal Fropil, 2 (2).

Anggraeni, F. D., Hardjanto, I., \& Hayat, A. (2013). Pengembangan Usaha Mikro, Kecil, dan Menengah (UMKM) Melalui Fasilitas Pihak Eksternal dan Potensi Internal. Journal Administrasi Publik (JAP), 1 (6), 1286-1295.

Badan Pusat Statistik (BPS). (2018). Hasil Pendataan Potensi Desa (Podes) Tahun 2018. Jakarta (ID): Badan Pusat Statistik.

Badan Pusat Statistik (BPS). (2019). Provinsi Jawa Tengah Dalam Angka 2019. Jawa Tengah: Badan Pusat Statistik.

Badan Pusat Statistik (BPS). (2020). Pedoman Penyusunan Indeks Desa. Jakarta (ID): Badan Pusat Statistik.

Budiarto, T., Rustiadi, E., \& Dharmawan, A. H. (2017). Perkembangan dan Kemandirian Desa di Kabupaten Bogor, Provinsi Jawa Barat. Journal Tataloka. 19 (3), 230-241.

Darwanto, Raharjo, S. T., \& Setiawan, A. H. (2018). Pengembangan Produksi Usaha Mikro, Kecil dan Menengah (UMKM) Sektor Pertanian Berbasis Potensi Lokal. Jurnal Riset Ekonomi Manajemen, 1 (2), 27-36.
Mishra, S. P., Sarkar, U., Taraphder, S., Datta, S. Swain, D. P., Saikhom, R., Panda, S., \& Laishram, M. (2017). Multivariate Statistical Data Analysis-Principal Component Analysis (PCA). International Journal of Livestock Research, 7 (5).

Murdianto \& Tri, G. (2015). Bencana Banjir dan Tanah Longsor dan Upaya Masyarakat dalam Penanggulangan. Jurnal Penelitian Kesejahteraan Sosial, 14 (2), 437-452.

Murtadho, A., Wulandari, S., Wahid, M., \& Rustiadi, E. (2018). Perkembangan Wilayah dan Perubahan Tutupan Lahan di Kabupaten Purwakarta sebagai Dampak dari Proses Konurbasi Jakarta-Bandung. Journal of Regional and Rural Development Planning, 2 (2), 195-208.

Naryanto, H. S., Soewandita, H., Ganesha, D., Prawiradisastra, F., \& Kristijanto, A. (2019). Analisis Penyebab Kejadian dan Evaluasi Bencana Tanah Longsor di Desa Banaran, Kecamatan Pulung, Kabupaten Ponorogo, Provinsi Jawa Timur Tanggal 1 April 2017. Jurnal Ilmu Lingkungan, 17 (2), 272-282.

Nishino, T. (2010). Present Conditions of Settlement of Mountain Villages and Viewpoints for Regional Policy. E-journal GEO, 4 (2).

Octavia, A., Gani, A., \& Arief, M. (2020). Dampak Penggunaan Dana Desa terhadap Indikator Ketahanan Sosial, Ekonomi dan Ekologi Desa Tertinggal Kecamatan Bulukumpa Kabupaten Bulukumba. Journal Ilmu Ekonomi, 3 (1).

Palupi, S., Ulfiah, U., Prasetyohadi. Sukapati, Y., \& Fauzi, S, A. (2016). Buku Panduan Pelaksanaan Undang-Undang Desa Berbasis Hak. Lakpesdam PBNU.

Panuju, D. R. \& Rustiadi, E. (2013). Teknik Analisis Perencanaan Pengembangan Wilayah. Institut Pertanian Bogor

Pratiwi, D, E. \& Harjoko, A. (2013). Implementasi Pengenalan Wajah Menggunakan PCA (Principal Component Analysis). Indonesia Journal of Electronics and Instrumentations Systems (IJEIS). 3 (2), 175-184.

Priyono, K. D., Priyana, Y. \& Priyono. (2006). Analisis Tingkat Bahaya Longsor Tanah di Kecamatan Banjarmangu Kabupaten Banjarnegara. Universitas Muhammadiyah

Rustiadi, E., Saefulhakim, S., \& Panuju, D. R. (2011). Perencanaan dan Pengembangan Wilayah Yayasan Pustaka Obor, 58-114. 
Sitinjak, D, A., Suryawardani, I. G. A. O., \& Wijayanti, P. U. (2017). Analisis FaktorFaktor yang Menentukan Kepuasan Kerja dan Loyalitas Karyawan. Journal Agribisnis dan Agrowisata, 6 (3).

Sriningsih, S., Astuti, E., \& Ismiwati, B. (2020). Implementasi PERMENDESAPDTTRANS No. 2 Tahun 2016 Terkait Status Desa di Desa Sukarara Lombok Tengah. Jurnal Kompetitif Media Informasi Ekonomi Pembangunan, Manajemen, dan Akuntansi, 6 (1), 71-81.

Tisniwati, B. (2021). Analisis Faktor-Faktor yang Mempengaruhi Tingkat Kemiskinan di Indonesia. Journal Ekonomi Pembangunan, 10 (1).

Usman, S., Widhyarto, D, S., \& Maika, A. (2010). Strategi Penciptaan Pelayanan Kesehatan Dasar untuk Kemudahan Akses Penduduk Desa Miskin. Jurnal Ilmu Sosial dan Ilmu Politik.

Yulitasari \& Tyas, W. P. (2020). Dana Desa dan Status Desa di Provinsi Jawa Tengah. Journal of Regional and Rural Development Planning, 4 (2). 74-83.

Zhou, Z., Jia, Z., Wang, N., \& Fang, M. (2018). Sustainable Mountain Village Construction Adapted to Livelihood, Topography, and Hydrology: A Case of Dong Villages in Southeast Guizhou, China. Journal of Sustainability (MDPI), 10 (4619).

Zollet, S. \& Qu, M. (2012). Organic Farming and Agricultural Landscape Preservation for the Sustainable Development of Uttarakhand Mountain Villages. Journal of Urban and Regional Studies on Contemporary India, 4 (2), 41-53 (2018). 